\title{
Feeding layers with different levels of energy and protein in the Eastern Province of Saudi Arabia
}

\author{
H. Appelman and B. J. Bonhof ${ }^{1}$
}

International Land Development Consultants N.V. (ILACO), Arnhem, the Netherlands.

Received: 17 May 1971

\section{Summary}

At the Qatif Experimental Farm² a trial was conducted comparing the production performance of single combed White Leghorn hybrids fed on a normal caloric - extra high-protein mash and a low caloric - high-protein mash. The experimental stock was kept both under insulated and ventilated housing conditions and under 'open' housing conditions.

The feeding of high-caloric mash tended to result in better production aspects, but these were offset by a higher mortality and higher price per $\mathrm{kg}$ of the mash.

Practising ventilation only under insulated housing conditions prevented outfall caused by heat stroke.

\section{Introduction}

In an earlier trial, in which layers in the Eastern Province were fed with standard European layer pellets, evidence was gained that the high-caloric feed induced excess fattiness in the hens. In order to study this phenomenon more closely a feeding trial with White Leghorn layers was conducted at the Qatif Experimental Farm. The feeds used consisted of a high-energy high-protein mash and a low-energy mash. As experimental stock one-day-old Single Combed White Leghorn hybrids were flown in. The raising period lasted from 8 November 1967 till 14 April 1968. The laying period was extended over 52 weeks till 14 April 1969.

\section{Purpose of the trial}

The trial was designed to study the influence of two feeds with different energy and protein levels on the productivity of laying hens.

\section{Feeds}

The feeds as given in Table 1 were locally prepared in a commercial mill established at Dammam. Owing to periodical shortage of wheatbran it was necessary to alter the low-caloric mash twice during the laying period. By substituting wheatbran by barley and

\footnotetext{
1 On detachment from the Central Institute for Poultry Research 'Het Spelderholt', Beekbergen, the Netherlands.

2 Jointly financed by the Saudi Arabian Goverment and U.N. Special Fund through FAO. The farm was established and managed by ILACO, Arnhem, the Netherlands, between 1964 and 1969.
} 
Table 1. The feeds used $(\mathrm{g} / \mathrm{kg})$.

\begin{tabular}{|c|c|c|c|c|c|}
\hline & $\begin{array}{l}\text { Chick } \\
\text { starter }{ }^{1}\end{array}$ & $\begin{array}{l}\text { Chick } \\
\text { developper }{ }^{2}\end{array}$ & $\begin{array}{l}\text { Pullet } \\
\text { grower }^{3}\end{array}$ & $\begin{array}{l}\text { High-caloric } \\
\text { layer mash }\end{array}$ & $\begin{array}{l}\text { Low-caloric } \\
\text { layer mash }\end{array}$ \\
\hline $\begin{array}{l}\text { Protein concentrate } \\
+\quad \text { amprolium }\end{array}$ & 125 & 100 & - & - & - \\
\hline Soybean oil meal & 150 & 125 & 75 & 280 & 170 \\
\hline Yellow corn & 575 & 575 & 600 & 615 & 505 \\
\hline Wheatbran & 150 & 200 & 250 & - & 220 \\
\hline Ground limestone & $\ldots$ & - & - & 30 & 30 \\
\hline Protein concentrate & - & - & 75 & 75 & 75 \\
\hline Total & 1,000 & 1,000 & 1,000 & 1,000 & 1,000 \\
\hline $\mathrm{MEC} / \mathrm{kg}$ & 2,740 & 2,680 & 2,625 & 2,832 & 2,496 \\
\hline Proteins $(\%)$ & 19.8 & 18.3 & 15.2 & 21.1 & 18.2 \\
\hline $\mathrm{C} / \mathrm{P}$ ratio $\mathrm{MEC} / \%$ Proteins & & & & 134 & 137 \\
\hline
\end{tabular}

: $0-6$ weeks; ${ }^{2} \quad 7-12$ weeks; $^{3} \quad 13-22$ weeks; $\geqslant 23$ weeks.

decreasing the amount of yellow corn the caloric value and protein content were maintained at $2,496 \mathrm{MEC} / \mathrm{kg}$ and $18.2 \%$, respectively.

\section{Design of the trial and facilities}

The available trial facilities were used to full capacity, permitting a design of 8 groups, ultimately totalling 995 layers at the onset of the laying period. Two groups were kept in insulated units equipped with ventilators. The remaining groups were kept in traditional open-air units, lined up under a corrugated galvanized sheet roof. All units measured $5.5 \times 7 \mathrm{~m}$. During the raising period all groups received standard feeds. During the laying period 4 groups were fed high-caloric (HC) mash and 4 groups received lowcaloric (LC) mash.

\section{Vaccination schedule}

The following schedule was adherend to:

at 3 weeks : New Castle Disease (Strain La Sota, water-solube) and Infectious Bronchitis (Strain H 120, water-soluble)

at 3 months: Revaccination Infectious Bronchitis (Strain H 52, water-soluble) and Fowlpox (feather follicle method)

at 5 months: Revaccination New Castle Disease (Strain La Sota, water-soluble)

\section{Illumination schedule and operation ventilators}

During the first month of the rearing period illumination was extended to a 24-hour day. In the second month the duration of light was gradually reduced to 12 hours a day until 3 weeks before the laying period. During the laying period a 17-hour lighting schedule was maintained. As it was found in a previous trial that air-conditioning was not a paying proposition, ventilation only was practised in the insulated units. Full-time ventilation proved to be necessary during the summer months.

\section{Result of the trial}

Chick-rearing period (8-11-1967 / 14-4-1968)

The results of the chick-rearing period were satisfactory, as is reflected in the summa- 
Table 2. Average weights and growth (g).

\begin{tabular}{llllll}
\hline & \multicolumn{2}{l}{ Weight } & & & \multicolumn{2}{c}{$\begin{array}{l}\text { Growth in } \\
159 \text { days }\end{array}$} \\
\cline { 3 - 5 } & initial & 49 days & 84 days & 159 days & \\
Groep 1 (insulated) & 38 & 643 & 1,140 & 1,844 & 1,806 \\
Group 2 (open) & 38 & 620 & 1,151 & 1,864 & 1,826 \\
\hline
\end{tabular}

Table 3. Feed consumption (g) and feed conversion. ${ }^{1}$

\begin{tabular}{lllll}
\hline & $\begin{array}{l}\text { Total feed } \\
\text { consumption } \\
\text { per chick } \\
\text { in 84 days }\end{array}$ & $\begin{array}{l}\text { Cumulative } \\
\text { feed } \\
\text { conversion } \\
\text { in } 84 \text { days }\end{array}$ & $\begin{array}{l}\text { Total feed } \\
\text { consumption } \\
\text { per chick } \\
\text { in 159 days }\end{array}$ & $\begin{array}{l}\text { Cumulative } \\
\text { feed } \\
\text { conversion } \\
\text { in 159 days }\end{array}$ \\
$\begin{array}{l}\text { Group 1 } \\
\text { (insulated) }\end{array}$ & 4,096 & 3.717 & 9,786 & 5.419 \\
$\begin{array}{l}\text { Group 2 } \\
\text { (open) }\end{array}$ & 4,284 & 3.849 & 10,120 & 5.542 \\
\hline
\end{tabular}

1 Feed intake $(\mathrm{kg})$ required for $1 \mathrm{~kg}$ growth.

Table 4. Losses (numbers).

\begin{tabular}{lccc}
\hline Causes of losses & Group 1 (insulated) & Group 2 (open) & Total \\
Undigested yolk & 6 & - & 6 \\
Diarrhoca & 1 & 1 & 2 \\
New Castle Disease' & 8 & 29 & 37 \\
Cannibalism & 9 & 5 & 14 \\
Accidents & 1 & 9 & 10 \\
No indications & 4 & 4 & 8 \\
Total numbers & 29 & 48 & 77 \\
Percentage & 9.7 & 5.2 & 6.3 \\
\hline
\end{tabular}

1 Not clinically confirmed, no laboratory facilities being available.

rized data concerning growth, feed consumption mortality and losses in Tables 2, 3 and 4. Two groups were included in this phase of the trial:

Group 1: insulated units (initial number 300 one-day-old chicks)

Group 2: open units (initial number 930 one-day-old chicks).

Athough the growth in both groups was nearly equal, the feed conversion tended to be more favourable in the insulated housing group.

Considering the climatic conditions in the Qatif Area, the overall mortality rate can be considered very favourable.

\section{Laying period (15-4-1968/14-4-1969)}

The initial number of layers ranged between 123 and 125 per trial unit. The results of the trial are summarized in Tables 5-10.

As there was practically no difference in productivity between the feed groups while the feed intake was higher in the low-caloric groups, the feed conversion was better in 
high-caloric groups. The energy and protein conversion, however, were more favourable in the low-caloric groups. Taking the climatic conditions into account, the average egg weights were acceptable.

Live-weights

During all phases of the laying period the hens in the high-caloric groups tended to be slightly heavier than those in the low-caloric groups. The final weights were normal for the hybrid used (Table 5).

Table 5. Average live-weights (g).

\begin{tabular}{llll}
\hline & $\begin{array}{l}\text { At start of } \\
\text { laying period } \\
(20-4-1968)\end{array}$ & $\begin{array}{l}\text { After 35 weeks } \\
\text { of production } \\
(16-12-1968)\end{array}$ & $\begin{array}{l}\text { At termination } \\
\text { of the trial } \\
(14-4-1969)\end{array}$ \\
$\begin{array}{l}\text { Insulated } \\
\text { house }\end{array}$ & & & \\
HC group 2 & 1,849 & 2,190 & 2,328 \\
LC group 1 & 1,838 & 2,115 & 2,250 \\
$\begin{array}{l}\text { Open house } \\
\text { HC group 3 }\end{array}$ & 1,853 & & \\
HC group 5 & 1,883 & 2,170 & 2,297 \\
HC group 7 & 1,882 & 2,220 & 2,353 \\
Average HC & 1,873 & 2,210 & 2,369 \\
groups & 1,837 & 2,200 & 2,340 \\
$\begin{array}{l}\text { LC group 4 } \\
\text { LC group 6 }\end{array}$ & 1,899 & 2,120 & 2,231 \\
LC group 8 & 1,842 & 2,155 & 2,269 \\
Average LC & 1,859 & 2,130 & 2,242 \\
groups & & 2,135 & \\
\hline
\end{tabular}

Table 6. Summary of feed consumption.

\begin{tabular}{|c|c|c|}
\hline & $\begin{array}{l}\text { Average feed consumption } \\
\text { per hen per day }(\mathrm{g})\end{array}$ & $\begin{array}{l}\text { Total feed consumption } \\
\text { per hen during the } \\
\text { laying period }(\mathrm{kg})\end{array}$ \\
\hline \multicolumn{3}{|l|}{ Insulated house } \\
\hline HC group 2 & 102.1 & 37.3 \\
\hline LC group 1 & 106.8 & 39.0 \\
\hline \multicolumn{3}{|l|}{ Open house } \\
\hline HC group 3 & 98.4 & 35.9 \\
\hline HC group 5 & 101.6 & 37.1 \\
\hline HC group 7 & 102.4 & 37.4 \\
\hline Average $\mathrm{HC}$ groups & 100.8 & 36.8 \\
\hline LC group 4 & 107.5 & 39.2 \\
\hline LC group 6 & 109.7 & 40.0 \\
\hline LC group 8 & 108.2 & 39.5 \\
\hline Average LC groups & 108.5 & 39.6 \\
\hline
\end{tabular}




\section{Feed consumption}

The feed consumption is summarized in Table 6. According to expectations the lowcaloric groups consumed more feed than the high-coloric groups.

\section{Egg production}

The figures of Table 7 and 8 indicate that there appeared to be no difference in egg production per hen housed between feed groups. The insulated housing groups, however, tended to be more productive than the open housing groups. Considering the climatic conditions it can be stated that the overall productivity was favourable indeed.

Table 7. Laying percentages and egg production by numbers.

\begin{tabular}{llll}
\hline & $\begin{array}{l}\text { Overall average } \\
\text { laying }(\%)\end{array}$ & Production of eggs & \\
\cline { 2 - 3 } & & per hen housed & \\
Insulated house & & 243 \\
HC group 2 & 66.7 & 216 & 232 \\
LC group 1 & 63.7 & 217 & \\
Open house & & & 227 \\
HC group 3 & 62.2 & 189 & 234 \\
HC group 5 & 64.2 & 199 & 232 \\
HC group 7 & 63.8 & 203 & 231 \\
Average HC groups & 63.4 & 197 & 227 \\
LC group 4 & 62.4 & 202 & 236 \\
LC group 6 & 64.7 & 192 & 226 \\
LC group 8 & 62.0 & 205 & 230 \\
Average LC groups & 63.0 & 200 & \\
\hline
\end{tabular}

Table 8. Egg production by weight and feed conversion.

\begin{tabular}{llll}
\hline & $\begin{array}{l}\text { Overall average } \\
\text { egg weights (g) }\end{array}$ & $\begin{array}{l}\text { total weight of } \\
\text { eggs produced (kg) }\end{array}$ & $\begin{array}{l}\text { Cumulative feed } \\
\text { conversion' }\end{array}$ \\
$\begin{array}{l}\text { Insulated } \\
\text { house }\end{array}$ & & \\
HC group 2 & 58.2 & 1,534 & 2.657 \\
LC group 1 & 58.4 & 1,556 & 2.893 \\
Open house & & & \\
HC group 3 & 59.5 & 1,391 & 2.681 \\
HC group 5 & 59.3 & 1,463 & 2.693 \\
HC group 7 & 59.2 & 1,489 & 2.736 \\
Average HC groups & 59.3 & 1,448 & 2.703 \\
& & & 2.920 \\
LC group 4 & 59.5 & 1,492 & 2.907 \\
LC group 6 & 59.0 & 1,387 & 2.980 \\
LC group 8 & 58.9 & 1,492 & 2.936 \\
Average LC groups & 59.1 & 1,457 & \\
\hline
\end{tabular}

1 Feed intake in $\mathrm{kg}$ to produce $1 \mathrm{~kg}$ of eggs. 
Table 9. Mortality, culling and total losses (\%).

\begin{tabular}{lrll}
\hline & Mortality & Culling & Total losses \\
$\begin{array}{l}\text { Insulated } \\
\text { house }\end{array}$ & & & \\
HC group 2 & 15.4 & 4.9 & 20.3 \\
LC group 1 & 7.3 & 4.8 & 12.1 \\
& & & \\
Open house & & 8.8 & 28.0 \\
HC group 3 & 19.2 & 4.8 & 23.2 \\
HC group 5 & 18.4 & 6.4 & 23.2 \\
HC group 7 & 16.8 & 6.7 & 24.8 \\
Average HC groups & 18.1 & 5.6 & 16.8 \\
& & 6.5 & 29.9 \\
LC group 4 & 11.2 & 2.4 & 16.9 \\
LC group 6 & 23.4 & 4.8 & 21.2 \\
LC group 8 & 14.5 & & \\
Average LC groups & 16.4 & 5.5 & 21.3 \\
Average all groups & 15.8 & & \\
\hline
\end{tabular}

\section{Losses}

Losses are given in Table 9. The main cause of mortality was visceral lymphomatosis, which accounted for about $50 \%$ of the total outfall. Practically all culled hens showed symptoms of ocular lymphomatosis. A total of 33 hens in the open housed groups died from heat stroke in July.

\section{Power consumption}

Although no air-conditioning was practised but only ventilation by wall ventilators in the insulated units there was still an appreciable difference in power consumption between the insulated and open housing units (Table 10).

It should be emphasized that the small units in question required relatively large equipment and inherently a large power consumption.

Table 10. Power consumption per experimental unit $(\mathrm{kW} h)$.

\begin{tabular}{lcc}
\hline & Insulated unit & Open housing unit \\
$\begin{array}{l}\text { Rearing period } \\
\text { ventilation } \\
\text { illumination }\end{array}$ & 8 & $\overline{72}$ \\
& $\frac{209}{217}$ & $\overline{72}$ \\
$\begin{array}{l}\text { Laying period } \\
\text { ventilation } \\
\text { illumination }\end{array}$ & 1,611 & - \\
& $\overline{495}$ & $\overline{204}$ \\
Total both periods & 2,106 & 276 \\
\hline
\end{tabular}




\section{Tentative conclusions}

As the available facilities did not allow a statistical analysis of the data obtained in the trial, the conclusions presented are of indicative value only:

- One-day-old Single Combed White Leghorn hybrids as used and reared in the trial can be successfully reared under climatic conditions as prevailed during the winter season 1967/68 in the Qatif Area.

- In comparing high- and low-caloric feeding on the production performance of White Leghorn hybrids the following indications were observed. High-caloric feeding resulted in a better egg production per hen laid, a lower feed intake and higher liveweights. However these favourable aspects were offset by a higher mortality rate and the higher price of the feed. Consequently financial results might be better in case of feeding a low-caloric mash.

- The keeping of White Leghorn layers under insulated housing conditions and practising ventilation only prevented losses caused by heat stroke. 